Religious Studies (2021) 57, 1-9 @ The Author(s), 2020. Published by Cambridge University Press doi:10.1017/S0034412520000426

\title{
Revd Dr David Efird: an academic tribute
}

\author{
JOSHUA COCKAYNE \\ School of Divinity, University of St Andrews, St Andrews, KY16 9JU, UK \\ e-mail:jlc22@st-andrews.ac.uk \\ DAVID WORSLEY \\ Department of Philosophy, University of York, York, North Yorkshire, YO10 5DD, UK \\ e-mail: david.worsley@york.ac.uk
}

The Revd Dr David Efird passed away at the beginning of 2020. He was 45 . David was a much-loved teacher and a leading figure in philosophy of religion in the UK. He was also the co-editor of this journal between 2016 and 2018.

\section{Early work}

Before arriving in the United Kingdom to study philosophy, David received degrees from Duke University and Princeton Theological Seminary. After completing his Master's degree at the University of Edinburgh, he moved to Oxford to work on his DPhil with Professor Timothy Williamson. David's thesis argued against the seemingly intuitive idea that there are contingent existents, claiming instead that everything that exists does so necessarily. ${ }^{1}$ David's expertise in modal metaphysics saw him attract a number of job offers, before accepting a lectureship at the University of York, where he remained until his death.

While David's last years were characterized by a focus on philosophy of religion, it was in metaphysics that he first built his reputation. Most notable among David's early work at York were a number of co-authored papers written with a colleague, Tom Stoneham, on the topic of metaphysical nihilism. ${ }^{2}$ These papers explored the contrary claim to that defended in his doctoral work on modality, namely, that it is possible that there could have been nothing. This collaborative endeavour set the tone for much of David's career in research. Stoneham recalls: 'This abiding commitment to priority of human relationships, and engaging with people around him, extended to his research . . . Looking over his publications list it is striking that in fifteen years of productive research, he only ever published five single-authored pieces and had 10 different co-authors.'3 


\section{Analytic theology as applied philosophy}

In the late 2000s, David's focus switched from metaphysics to philosophy of religion. This change coincided with the publication of Michael Rea's Oxford Readings in Philosophical Theology and Rea and Oliver Crisp's Analytic Theology. David was happy to adopt the title of an analytic theologian, but he was clear about what this meant to him. In his view, analytic theology was applied philosophy, not theology, and was an enterprise open to all philosophers.

This way of thinking about analytic theology was often illustrated by David with a comparison to the study of physics and the study of the philosophy of physics (an area he taught for many years). As David saw it, a similar relationship existed between the study of Christian theology and the study of the philosophy of Christian theology. In particular, David saw philosophy as giving philosophical explanations to philosophical problems. ${ }^{4}$ If a theological claim could be presented as a philosophical problem, it fell into the philosopher's remit. Once so identified, one was to proceed by identifying (or developing) a series of philosophical explanations, analysing their consequences, and endorsing the most viable explanatory candidate. In what would be his last conference paper, David presented an essay on David Lewis's place in the history of analytic theology. In that paper, David wrote:

Lewis's methodology, as outlined in his introduction to the first volume of his Philosophical Papers, paves the way for analytic theology, which, I also argue, is a branch of philosophy, and not theology. On this methodology, philosophy is an exercise in a cost/benefit analysis, something that can be done regardless of one's commitments. This methodology is perfectly placed to make progress in analytic theology, or so I maintain. Analytic theology, I argue, is really philosophy, and not theology, if we take theology to be the study of a person, namely, God, and philosophy to be the pursuit of a universal, namely wisdom, or understanding. If we take philosophy and theology in this way, then analytic theology is a kind of philosophy, since it aims to further theological understanding by the use of concepts, views, and arguments in analytic philosophy. Given this methodology and this conception of analytic theology, I argue, atheists can make as much of a contribution to analytic theology as theists can.

David's enthusiasm for analytic theology initially focused on an analysis of traditional Christian doctrines. In 2009, David established an MA at York in Philosophy, Theology, and Ethics, and shortly thereafter, began offering an immensely popular final-year module on the Philosophy of Christianity. His teaching on both followed his research methodology: presenting a doctrine in its historical context (Trinity, Incarnation, Atonement, etc.), identifying philosophical problems with the doctrine as so presented, and then providing (and performing a series of cost/benefit analyses) on a handful of philosophical solutions to this problem.

David's modules on the Philosophy of Christianity were significant for many of his students. For some, it was their first introduction to Christian doctrine and David encouraged many to pursue further study in this area. David's teaching in philosophy of religion and analytic theology also fed naturally into his research 
group, 'The St. Benedict Society for Philosophy of Religion and Philosophical Theology', a group whose members included faculty, graduate students, and undergraduate students. As David described it, 'St Benedict established an order founded on principles of mutuality, moderation, and encouragement. We aim to embody those values in working collaboratively to produce high-quality research in the philosophy of religion and philosophical theology.' The group focused on providing feedback on works in progress, discussing new research articles, and developing collaborative projects. David was particularly proud of an article the group published together titled, 'Experiencing the Real Presence of Christ in the Eucharist'. The paper was co-authored by no less than eight authors, including an undergraduate student and a number of postgraduate students.

\section{Analytic spirituality}

David's turn to thinking philosophically about theological concepts was always more than a mere intellectual curiosity. As an assistant priest in his local parish church, he could often be found running pub theology nights for his congregants, or delivering public lectures in York Minster, taking time to translate his research to the lives of ordinary people. For David, the divide between academic work and pastoral ministry was not always sharp.

It was not surprising, then, that David's work in analytic theology led him to think seriously about the philosophical implications of the spiritual life. In the summer of 2013, David was invited to review Eleonore Stump's Wandering in Darkness for The Philosophical Quarterly. As David later noted, this book would have a profound effect on both his personal life and the direction his future research would take. ${ }^{5}$ He was inspired by Stump's claim that suffering is a mode of, and an occasion for, a second-person experience of God. In this experience of God, a person can come to a personal knowledge of God that cannot be reduced to knowing propositions about God, with such knowledge central to a person's union with God. Much of David's subsequent work focused on what it is to know God personally, in this life and the next, an area of study he titled 'analytic spirituality'.

Building on this account of knowing God personally through second-personal encounters, David worked on a number of projects (typically, collaborative) which applied these concepts to the life of faith. His published work addressed topics such as what it is to experience God through Christian art, ${ }^{6}$ how the Eucharist might be thought of in second-personal terms, ${ }^{7}$ the role of corporate liturgy in knowing God, ${ }^{8}$ and the ways in which friendship with God changes our understanding of petitionary prayer. ${ }^{9}$ In The T\&T Clark Companion to Analytic Theology, the first major thematic overview of analytic theology as a discipline, David was given an opportunity to map out the contours of analytic spirituality. ${ }^{10}$ Here, David painted a vision for an analytic philosophy of spirituality rooted in a second-personal knowledge of God, bringing together important 
insights from his various articles and chapters. Summarizing his approach to Christian spirituality, David wrote:

the goal of the spiritual life is to grow in the knowledge and the love of God. This is (however falteringly) accomplished through inward disciplines such as meditation, prayer, fasting, and study; outward disciplines such as simplicity, solitude, submission, and service; and corporate disciplines such as confession, worship, guidance, and celebration. ${ }^{11}$

It is in attempting to analyse what it is to know God personally that we can turn to analytic philosophy to help our vision of Christian spirituality, or so David argued. In his conclusion, he summarizes:

What analytic philosophy helps with is clarification, clarification, that is, through conceptual engineering. For, when we try to understand what it is to know God personally, we cannot take this as simply another case of knowing another person. We have to modify our concept of personal knowledge and the skills necessary for acquiring such knowledge. ${ }^{12}$

It is in studying scripture and allowing the texts of scripture to occasion a secondpersonal encounter with God that such knowledge arises. One of David's many unfinished projects was to offer a sustained account of how scripture might be read in this way.

\section{Spirituality and the beatific vision}

In David's view, the central question in the study of the spiritual life was this: if we are made for union with God, why are we not already so united? ${ }^{13} \mathrm{He}$ thought that one possible answer to this question could be found in developing a verse from the New Testament: 'For now we see in a mirror, dimly, but then we will see face to face. Now I know only in part; then I will know fully, even as I have been fully known' (1 Corinthians 13:12). If union requires knowledge, while in this life we might come to know God imperfectly, and so unite imperfectly, a time will come when, at the beatific vision, a person will know God perfectly, even as they are known by God.

In 2016, David received a grant to work on analytic approaches to the beatific vision. From this grant came a series of papers, and an edited issue of the TheoLogica journal. ${ }^{14}$ One of David's major contributions to this topic was to argue that we could come to know God personally, even if God was propositionally ineffable, ${ }^{15}$ and that appropriately attending to such personal knowledge would invariably cause a person to desire God. ${ }^{16}$

In 2017, David was appointed the first chair of the UK branch of the Society of Christian Philosophers (SCP). David chose as the topic of the first SCP: UK conference the beatific vision. As had now been customary for any project overseen by David, the SCP: UK was to be a society founded on mutual respect and charity, prioritizing excellence in philosophical research, while making this as accessible as possible to anyone who was interested. David invested much of his own research 
budgets into securing world-leading scholars to contribute to the society's meeting and to offer bursaries to anyone who was unable to attend due to lack of resources.

\section{Centring marginalized voices}

Any student entering David's office would have been struck by the large icon of the Good Shepherd hanging on the wall. Its placement was intentional to remind David of the infinite value and worth of each individual he worked with or taught. David also served in a number of pastoral roles at York, devoting time to supporting and mentoring hundreds of students. He was especially gifted at noticing students who felt ostracized or underconfident and helping them to realize their true potential. His ability to spot the lost sheep, and to nurture them, was uncanny.

It was this approach to philosophy that led David to focus many of his final research projects on issues which had typically been ignored by philosophers of religion. The introduction to a recent volume David contributed to sums this approach up well. The editors, Kevin Timpe and Blake Hereth wrote: 'we think philosophy of religion would benefit from widening or diversification in a number of ways - by bringing more sheep into the fold . . our volume seeks to direct attention to both underrepresented topics and persons within philosophy of religion'. ${ }^{17}$ For David, this meant turning the discussion in analytic theology to think about two voices in particular: LGBTQ+ persons who had been sidelined and pushed away from faith communities, ${ }^{18}$ and those with disabilities. ${ }^{19}$ Before he passed away David was working on a project exploring the epistemology of testimony for victims of abuse and had presented material on this topic on a number of occasions.

In a recent volume in the 'Oxford Studies in Analytic Theology' series, Voices from the Edge, David considered how it could be that lesbian and gay people who had suffered trauma at the hands of religious communities could lose their faith in God. True to form, David focused on what it is to know God personally, arguing that the communities we belong to can have a detrimental effect on a spiritual life aimed at knowing God. He wrote:

\footnotetext{
using religious texts and rituals, church members can shame one of their own, particularly a lesbian or gay Christian, to the extent that they come to lose their faith in God. Feeling ashamed, they no longer want the things that make up having faith in God - spending time with him, sharing their thoughts and feelings about important things with him, and wanting to have relationship with him. They don't want these things because they feel it's not right, or it makes them feel bad about themselves, or they just can't any more. ${ }^{20}$
}

David was unafraid to allow personal experience and relationships to shape his approach to philosophy. These final projects lacked none of the philosophical rigour of his early work but spoke meaningfully and powerfully into the lives of people who are often absent or silenced from philosophy of religion. 


\section{Unfinished ideas and legacy}

There were many projects and ideas that David did not finish. He was in the process of establishing a new Master's course at York that would seek to broaden the conversation in analytic theology to other faiths. As David saw it, the approach to analytic theology he had pioneered at York laid the groundwork for bringing Christian analytic theology into dialogue with Judaism and Islam. 'Comparative analytic theology', as David had described this endeavour, was just one of the many new directions he had hoped analytic theologians would expand into.

David's computer was filled with an endless list of co-authored projects which were in draft form, waiting for that final piece of inspiration, or mulling over the knock-down objection received at a conference or research presentation. Some of these projects will never see the light of day, but David's legacy in philosophy of religion is far from finished. His unique approach to research will continue to guide the directions of those who have worked with David or studied under him.

\section{Paying tribute to David's legacy}

This issue of Religious Studies is devoted to David's memory and pays tribute to many of his interests.

First, the issue contains a symposium, organized by David, on Eleonore Stump's recent book Atonement. As Stump notes in the book's preface, Atonement is a natural sequel to her Wandering in Darkness, the book that had such a profound effect on David's life and faith. David had been part of a group which met to review early drafts of Stump's work, and he was keen for Religious Studies to feature a symposium on the final draft. This symposium features contributions from Faith Pawl, Anne Jeffrey, and Kathryn Pogin, as well as a response by Eleonore Stump.

Second, the issue features two of his hitherto unpublished book reviews. Here, he reviews Divine Agency and Divine Action by William J. Abraham, and Maximal God by Yujin Nagasawa.

Finally, given David's legacy of investing in postgraduate students and junior scholars, it was deemed fitting that the Religious Studies annual postgraduate essay prize be renamed in his honour. David always encouraged his students to submit their work to this prize and he devoted countless hours to helping them begin their publishing careers. This issue features the essay of the first winner of the newly named 'David Efird Postgraduate Essay Prize', Nuno Maia's essay, 'Theistic Modal Realism and Causal Modal Collapse'.

\section{Selected list of publications}

'Unfenced existence: the logic and existence of necessary beings' (DPhil Thesis, University of Oxford, 2002). with Tom Stoneham, 'Genuine modal realism and the empty world', European Journal of Analytic Philosophy, 1 (2005), 21-38. 
with Tom Stoneham, 'The subtraction argument for metaphysical nihilism', The Journal of Philosophy, 102

(2005), 303-325.

with Tom Stoneham, 'Truthmaking and possible worlds', Analysis, 65 (2005), 290-294.

with Tom Stoneham, 'Combinatorialism and the possibility of nothing', Australasian Journal of Philosophy, 84

(Special issue on 'The Philosophy of D. M. Armstrong') (2006), 269-280.

with Tom Stoneham, 'What is the principle of recombination?', Dialectica, 62 (2008), 483-494.

with Tom Stoneham, 'Justifying metaphysical nihilism: a response to Cameron', The Philosophical Quarterly, 59 (2009), 132-137.

with Tom Stoneham, 'Is metaphysical nihilism interesting?', Pacific Philosophical Quarterly, 90 (2009), 210-231. with Tom Stoneham, 'The subtraction argument for the possibility of free mass', Philosophy and Phenomenological Research, 80 (2009), 50-57.

'Disjunctive permissions and epistemic modality', in Bob Hale \& Aviv Hoffman (eds) Modality: Metaphysics, Logic, and Epistemology (Oxford: Oxford University Press, 2009), 97-109.

'Is Timothy Williamson a necessary existent?', in Bob Hale \& Aviv Hoffman (eds) Modality: Metaphysics, Logic, and Epistemology (Oxford: Oxford University Press, 2009), 253-256.

'Divine command theory and the semantics of quantified modal logic', in Erik Wielenberg \& Yujin Nagasawa (eds) New Waves in Philosophy of Religion, (Basingstoke: Palgrave Macmillan, 2009), 91-104.

'Polarized yet warranted Christian belief', in Yujin Nagasawa (ed.) Scientific Approaches to the Philosophy of Religion (Basingstoke: Palgrave Macmillan, 2012), 224-236.

with Tom Stoneham, 'Methodological separatism, modal pluralism and metaphysical nihilism', in Tyron Goldschmidt (ed.) The Puzzle of Existence: Why is There Something Rather Than Nothing? (Abingdon \& New York: Routledge, 2013), 144-167.

with David Worsley, 'Critical review of Wandering in Darkness: Narrative and the Problem of Suffering by Eleonore Stump', The Philosophical Quarterly, 65 (2015), 547-558.

with Daniel Gustafsson, 'Experiencing Christian art', Religious Studies, 51 (2015), 431-439.

with Joshua Cockayne, Daniel Molto, Richard Tamburro, \& Jack Warman, 'Non-evidential believing and permissivism about evidence: a reply to Dan-Johan Eklund', Religious Studies, 53 (2015), 87-95.

with Joshua Cockayne, Gordon Haynes, August Ludwigs, Daniel Molto, Richard Tamburro, \& Jack Warman, 'Experiencing the real presence of Christ in the Eucharist', Journal of Analytic Theology, 5 (2017), 175-196. with David Worsley, 'Divine action and operative grace', The Heythrop Journal, 58 (2017), 771-779.

with David Worsley, 'What an apophaticist can know: divine ineffability and the beatific vision', Philosophy and Theology, 29 (2017), 205-219.

with Joshua Cockayne, 'Common worship', Faith and Philosophy, 35 (2018), 229-325.

with Stephen Holland, 'Stages of life: a new metaphysics of conceptionism', Bioethics, 33 (2019), 529-535.

'The resurrection of the minority body: physical disability in the life of heaven', in Blake Hereth \& Kevin Timpe (eds) The Lost Sheep in Philosophy of Religion: New Perspectives on Disability, Gender, Race, and Animals (Abingdon \& New York: Routledge, 2019), 211-240.

with David Worsley, "So that where I am, there you may be also": divine action and divine providence in the beatific vision', in Oliver D. Crisp \& Fred Sanders (eds) Divine Action and Providence: Explorations in Constructive Dogmatics (Grand Rapids MI: Zondervan, 2019), 206-222.

with Joshua Cockayne \& Jack Warman, 'Shattered faith: deconversion by spiritually violent religious trauma', in Michelle Panchuk \& Michael Rea (eds) Voices from the Edge: Centring Marginalized Perspectives in Analytic Theology (Oxford: Oxford University Press, 2020), 119-139.

'Analytic spirituality', in James Arcadi \& James T. Turner Jr. (eds) The T\&T Clark Handbook of Analytic Theology (London: T\&T Clark, 2021).

\section{References}

Cockayne, J. L., Efird, D., Haynes, G. P., Molto, D. V., Tamburro, R. A. S., Warman, J. R., \& Ludwigs, A. (2017) 'Experiencing the real presence of Christ in the Eucharist', Journal of Analytic Theology, 5, 175-196.

Cockayne, J. \& Efird, D. (2018) 'Common worship', Faith and Philosophy, 35, 299-325.

Cockayne, J., EFIRD, D. \& WARMAn, J. (2020) 'Shattered faith: the social epistemology of deconversion by spiritually violent religious trauma', in M. Panchuk \& M. Rea (eds) Voices from the Edge: Centering Marginalized Perspectives in Analytic Theology (Oxford: Oxford University Press), 119-139. 
EFIRD, D. (2002) ‘Unfenced existence: the logic and existence of necessary beings’ (D Phil Thesis, University of Oxford).

EFIRD, D. (2019) 'The resurrection of the minority body', in B. Hereth \& K. Timpe (eds) The Lost Sheep in Philosophy of Religion: New Perspectives on Disability, Gender, Race, and Animals (Abingdon \& New York: Routledge), 211-240.

EFIRD, D. (2021) 'Analytic spirituality', in J. Arcadi \& J. T. Turner Jr. (eds) The T\&T Clark Handbook of Analytic Theology (London: T\&T Clark).

Efird, D. \& Gustafsson, D. (2015) 'Experiencing Christian art', Religious Studies, 51, 431-439.

EFird, D. \& Stoneham, T. (2005a) 'Genuine modal realism and the empty world', European Journal of Analytic Philosophy, 1, 21-37.

EFIRD, D. \& STONEham, T. (2005b) 'The subtraction argument for metaphysical nihilism', The Journal of Philosophy, 102, 303-325.

Efird, D. \& Stoneham, T. (2006) 'Combinatorialism and the possibility of nothing', Australasian Journal of Philosophy, 84, 269-280.

Efird, D. \& Stoneham, T. (2009) 'Is metaphysical nihilism interesting?', Pacific philosophical quarterly, 9o, 210231.

EFiRd, D. \& Sтоnенам, T. (2014) 'Methodological separatism, modal pluralism, and metaphysical nihilism', in Tyron Goldschmidt (ed.) The Puzzle of Existence: Why Is There Something Rather Than Nothing? (Abingdon \& New York: Routledge, 2013), 144-167.

EFIRD, D. \& WARMAN, J. (MS) 'Is it ever rational to believe that God answered your prayer?'.

EfirD, D. \& Worsley, D. (2017a) 'Divine action and operative grace', The Heythrop Journal, 58, 771-779.

EFIRD, D. \& WorsLeY, D. (2017b) 'What an apophaticist can know: divine ineffability and the beatific vision', Philosophy and Theology, 29, 205-219.

EFIRD, D. \& WorsLey, D. (2018) 'Editorial: beatific vision', TheoLogica, 2, 1-2.

EFIRD, D. \& WorsLey, D. (2019) “"So that where I am, there you may be also": divine action and divine providence in the beatific vision', in O. D. Crisp \& F. Sanders (eds) Divine Action and Providence: Explorations in Constructive Dogmatics (Grand Rapids MI: Zondervan), 206-222.

Hereth, B. \& Timpe, K. (eds) (2019) The Lost Sheep in Philosophy of Religion: New Perspectives on Disability, Gender, Race, and Animals (Abingdon \& New York: Routledge).

\section{Notes}

1. Efird (2002).

2. These include: Efird \& Stoneham (2005a; 2005b); Efird \& Stoneham (2006); Efird \& Stoneham (2009); Efird \& Stoneham (2014).

3. <www.thebspr.org/app/download/10484051/DE+Tribute+-+Tom+Stoneham.pdf>.

4. In this way, David saw himself following in the footsteps of Robert Nozick's conception of philosophy.

5. In his introduction to a public lecture Eleonore Stump would later give in York, David noted that it was while reading Wandering, 'Even though [he] had been a lifelong Christian, that for the first time the nature of God's relationship to [him], to you, and to the whole world' was made clear to him. He continued, 'I came to understand myself differently, came to understand the world differently, and came to understand how I wanted to live my life differently.'

6. Efird \& Gustafsson (2015), 431.

7. Cockayne et al. (2017).

8. Cockayne \& Efird (2018).

9. Efird \& Warman (MS).

10. Efird (2021).

11. Ibid., 1.

12. Ibid., 14 .

13.

'You have made us for Yourself, and our hearts are restless until they rest in You', so Augustine addresses God at the beginning of his Confessions. According to Bishop Robert Barron, 'Everything else in the psychological and spiritual life is essentially a footnote to [this] statement'. This paper 
concerns the problem at the heart of Augustine's address, and at the heart of the spiritual life: if God has made us for himself, why are our hearts not already at rest in him? (Efird \& Worsley (2019), 207)
14. Efird \& Worsley (2018).
15. Efird \& Worsley (2017b).
16. Efird \& Worsley (2017a).
17. Hereth \& Timpe (2019), 9.
18. Cockayne et al. (2020), 119.
19. Efird (2019), 25.
20. Cockayne et al. (2020), 137. 